\title{
AIRBORNE GEOPHYSICAL DATA ANALYSIS APPLIED TO GEOLOGICAL INTERPRETATION IN THE ALTA FLORESTA GOLD PROVINCE, MT
}

\author{
Danilo Barbuena ${ }^{1}$, Carlos Roberto de Souza Filho ${ }^{1}$, Emilson Pereira Leite ${ }^{1}$, \\ Emílio Miguel Junior ${ }^{1}$, Rafael Rodrigues de Assis ${ }^{1}$, Roberto Perez Xavier ${ }^{1}$, \\ Francisco José Fonseca Ferreira² and Antônio João Paes de Barros ${ }^{3}$
}

\begin{abstract}
The Alta Floresta Gold Province (AFGP) is located in the central-southern portion of the Amazon Craton. In its eastern segment there are more than one hundred gold deposits hosted in volcanic and plutonic rocks of medium to high content of potassium. In many of these deposits the gold ore is correlated spatially and genetically related to magmatic-hydrothermal systems and mainly hosted into the silicification, potassic and sericitic alterations. In this context, this work focuses on understanding the geological context of the region and the possibility of expanding new exploratory frontiers through techniques further traditional geological mapping. The processing and interpretation of airborne magnetic and gamma-ray spectrometry data of the Juruena-Teles Pires Project (Phase 1) allowed the production of a new regional geological map of the eastern portion of the AFGP. Additionally, theoretical models showed that despite the limitations of the reduction to the pole at low latitudes, the magnetic enhancements proposed can be applied to real data through the use of directional filtering to eliminate the features generated in the magnetic declination direction. The Total Horizontal Derivative of the Tilt Derivative (THDR-TDR) method proved the best enhancement for the interpretation of the structures, showing a structural complexity similar to that proposed for the evolution of the province. The interpretation of the products based on the gamma-ray spectrometry channels allowed the reinterpretation of different geological units, including the individualization of a new high-potassium intrusive unit, which in the context of AFGP may have metallogenetic potential.
\end{abstract}

Keywords: Alta Floresta Gold Province, airborne geophysical data, geological interpretation.

RESUMO. A Província Aurífera de Alta Floresta (PAAF) situa-se na porção centro-sul do cráton Amazônico. Em seu segmento leste, ocorrem mais de uma centena de depósitos auríferos hospedados em rochas plutônicas e vulcânicas de médio a alto potássio. Além disso, em muitos desses depósitos o minério aurífero apresenta relação espacial e genética com alterações hidrotermais, preferencialmente alterações do tipo potássica e sericítica. Nesse contexto, o trabalho enfoca 0 entendimento do contexto geológico dessa região e a possibilidade de expansão de novas fronteiras exploratórias por meio de técnicas que vão além do mapeamento geológico tradicional. Assim, através do processamento e interpretação de dados aeromagnetométricos e aerogamaespectrométricos do projeto Juruena-Teles Pires (Fase 1) gerou-se um novo mapa geológico regional da porção leste da PAAF. Adicionalmente, por meio de modelos teóricos observou-se que apesar das limitações da redução ao polo em baixas latitudes, os realces magnéticos propostos podem ser aplicados aos dados reais mediante o uso de filtros direcionais que eliminem os artefatos gerados na direção da declinação magnética. 0 método Inclinação do Sinal Analítico do Gradiente Horizontal Total (ISA-GHT) mostrou-se como o realce mais adequado para a interpretação de lineamentos, revelando uma complexidade estrutural similar àquela proposta para a evolução da província. A interpretação dos produtos gerados com base nos canais gamaespectrométricos permitiu a reinterpretação de diversas unidades geológicas, inclusive a individualização de uma nova unidade intrusiva de alto potássio, que no contexto da PAAF pode possuir potencial metalogenético.

Palavras-chave: Província Aurífera de Alta Floresta, dados aerogeofísicos, interpretação geológica.

\footnotetext{
$1_{1}$ Instituto de Geociências, Universidade Estadual de Campinas - UNICAMP, R. João Pandiá Calógeras, 51, Cidade Universitária Zeferino Vaz, P.0. Box 6152, 13083-970 Campinas, SP, Brazil. Phone: +55(19) 3521-4653; Fax +55(19) 3289-1562 - E-mails: danilobarbuena@hotmail.com; beto@ige.unicamp.br; emilson@ige.unicamp.br; emiliogel@yahoo.com.br; rafael.assiss@gmail.com; xavier@ige.unicamp.br

2Laboratório de Pesquisas em Geofísica Aplicada, Universidade Federal do Paraná (UFPR), Centro Politécnico, Jardim das Américas, P.0. Box 19001, 81531-990 Curitiba, PR, Brazil. Phone/Fax +55(41) 3361-3132 - E-mail: francisco.ferreira@ufpr.br

3 Empresa Matogrossense de Mineração (METAMAT), Av. Gonçalo Antunes de Barros, 2970, Planalto, 78050-300 Cuiabá, MT, Brazil. Phone: +55(65) 3613-9000; Fax +55(65) 3653-2447 - E-mail: ajpbbb@gmail.com
} 


\section{INTRODUCTION}

The advance of scientific exploration frontiers to inaccessible areas has increased the demand for indirect methods to support geological mapping and mineral prospecting. One example is the geophysical data that contribute for determining the geological features in the subsurface (e.g. Dickson \& Scott, 1997; Fornazzari \& Ferreira Neto, 2003; Ferreira et al., 2010).

The magnetometry, in association with gravity, traditionally used as support for regional geological mapping, has experienced a major technological breakthrough in these last decades, especially with the emergence of high sensibility and precise instruments, accompanied by advances in modeling and interpretation software. This has contributed to increase the use of such data in geological mapping and mineral exploration projects.

Gamma-ray spectrometry also experienced major technological advances, especially with the introduction of more sensitive and accurate high resolution gamma spectrometer.

The use of geophysical data, in association with other methods of spatial and spectral analysis (e.g. remote sensing) and modeling through the integration of multisource data, are efficient in determining the characteristics of subsurface materials and identify new targets with potential for exploration.

The Alta Floresta Gold Province (AFGP), located in the central-north portion of Mato Grosso state, reached the height of its gold production between the 1970s and 1990s (Moreton \& Martins, 2005), but is still considered one of the major gold producing regions in Brazil. However, few studies conducted in the AFGP used exploratory methods that transcend traditional ones used in geological mapping campaigns. This is possibly a limiting factor for the results obtained in mineral exploration in the region, especially when identifying medium to high potassium granites and hydrothermal alteration zones, characteristics related to gold mineralization in the region (e.g. Paes de Barros, 1994; Santos et al., 2001; Paes de Barros, 2007; Assis, 2008, 2011; Miguel Jr. 2011).

In this context, the objective of this study is to analyze the airborne geophysical data of the Juruena-Teles Pires Project (Phase 1) (CPRM, 1991; BARMP, 1997) in order to: (i) improve the delineation of geological units, (ii) identify structures placed in different crust levels, (iii) individualize possible granitic bodies still unmapped, and (iv) analyze the theoretical magnetic data and predict possible defect that may influence the interpretation of real data.

\section{GEOLOGICAL CONTEXT}

The Alta Floresta Gold Province (AFGP) is located in the southcentral portion of the Amazon Craton, an elongated NW-SE area.
It is bordered to the north by the Cachimbo graben, separating it from the Tapajós Gold Province, and to the south by the Caiabis graben and Dardanelos Chapada. Depending on the tectonic model adopted, AFGP can be inserted in different provinces: Tapajós-Parima (2.03 to $1.88 \mathrm{Ga}$ ) and RondôniaJuruena (1.82 to $1.54 \mathrm{Ga}$ ), according to Santos et al. (2006) and Ventuari-Tapajós (1.95 to $1.80 \mathrm{Ga}$ ) and Rio Negro-Juruena (1.80 to $1.55 \mathrm{Ga}$ ) according to Tassinari \& Macambira (1999).

Regardless of the proposed compartment division, geological, geochemical and isotopic data indicate that the plutonicvolcanogenic units that make up these provinces were generated in magmatic arc environment that developed and was progressively aggregated to the proto-craton formed by the Central Amazon Province during the Paleoproterozoic (Tassinari \& Macambira, 1999; Souza et al., 2005; Santos et al., 2006; Silva \& Abram, 2008).

As the geological and metallogenic knowledge about the province advanced, especially its southeastern sector (e.g. Paes de Barros, 1994; Santos et al., 2000, Santos et al., 2001, 2006; Abreu, 2004; Bizotto, 2004; Moreton \& Martins, 2005; Souza et al., 2005; Paes de Barros, 2007; Silva \& Abram, 2008; Assisi, 2008, 2011; Barbuena, 2009), several genetic models have been proposed for the gold deposits in the region: (i) orogenic deposits in metamorphosed magmatic arc rocks (e.g. Complex Cuiú-Cuiú) (Paes de Barros, 1994; Santos et al., 2001), (ii) epizonal deposits related to felsic intrusive (intrusion-related gold systems), of disseminated style and/or stockwork systems (Santos et al., 2001; Paes de Barros, 2007; Assis, 2008), and (iii) the porphyry gold mineralization disseminated in Paleoproterozoic calc-alkaline granites (Moura, 1998; Moura et al., 2006; Assis, 2011).

However, the consensus among several authors (Moura, 1998; Paes de Barros, 2007; Silva \& Abram, 2008; Assis, 2008, 2011 ) is that a considerable portion of these deposits are spatially and temporally related to Paleoproterozoic granitic suites of type I, with sub-alkaline to calc-alkaline affinity, meta to peraluminous, medium to high potassium, magnesium to slightly ferrous. These granitic plutons were possibly intruded into suites that have been originated in an active continental margin onset with Archaean crustal source contributions (Moura, 1998; Paes de Barros, 2007; Silva \& Abram, 2008; Assis, 2008).

Moreover, many of these gold mineralizations are spatially and genetically related to hydrothermal alterations. In the southeastern portion of the province, the propylitic alteration with paragenesis consisting of epidote \pm chlorite \pm carbonate is the one with the most regional character. On the other hand, the alterations (i) potassium with potassium feldspar, (ii) sericitic with sericite/muscovite, (iii) albitic with albite and quartz, and 
(iv) argillic with kaolinite and sericite, are generally located in areas close to where the ore is hosted in granitic rocks (Assis, 2011).

The eastern sector of the AFGP, essentially contained in the Vila Guarita (SC.21-Z-B), presents some controversies regarding its stratigraphy, particularly concerning the nature of its basement. Moreton \& Martins (2005) admit that the basement of the province is represented by granitic to tonalitic gneisses of the Cuiú-Cuiú Complex. Souza et al. (2005) add to the basement, in addition to the Cuiú-Cuiú Complex, an association of supra crustal and plutonic rocks, metamorphosed in amphibolite and granulite facies, called the Bacaeri-Mogno Complex. Paes de Barros (2007) also notes that the AFGP basement, in its eastern sector, may contain representatives of the Xingu Complex (Silva et al., 1980), mainly due to the age of $2816 \pm 4$ Myr obtained in paleosome of the Gavião gneiss and also by the absence of typical orogenic associations similar to those described for the Cuiú-Cuiú Arc.

Besides the basement rocks, the eastern sector of the AFGP comprises (i) Nhandu Granite, (ii) Matupá Intrusive Suite, cut and enclosed by (iii) Flor da Serra Intrusive Suite. These two suites were interpreted by Vasquez et al. (2002) as a probable extension of the post-collisional granite bodies of the Cuiú-Cuiú Arc. Subsequently, in the Orosinian-Estaterian transition, forms the (iii) Juruena Intrusive Suite followed by (iv) Paranaíta Intrusive Suite and (v) Colíder Suite. Followed by the occurring units (vi) São Pedro Granite and (vii) Nova Canaã Suite, followed by (viii) Teles Pires Suite (Rizzotto et al., 2004; Moreton \& Martins, 2005; Souza et al., 2005; Silva \& Abram, 2008) (Fig. 1).

The Mesoproterozoic is represented by the Caiabis Group (Dardanelos Formation), consisting of sandstones, siltstones, mudstones, and basal conglomerates and by the Beneficente Group. Finally, the Cenozoic is represented by Tertiary-Quaternary Coverage and Alluvial Deposits, dominated by mudstones and clastic sediments, unconsolidated (Moreton \& Martins, 2005) (Fig. 1).

Paes de Barros (2007), based on field reconnaissance, geochemical and geochronological data, identifies for the Peixoto de Azevedo-Novo Mundo region, distinct geological units that have not been described previously, establishing the following stratigraphy: (i) Basement Gneisses and Migmatites, (ii) Basement Granitoids, (iii) Novo Mundo Granite, (iv) Matupá Granite, (v) Nhandu Granite, (vi) Peixoto Granite, (vii) Vulcan-Plutonic Teles Pires Suite, (viii) Beneficente Group and (ix) Alluvial Deposits.

Recent mapping work, based on petrography, geochemistry and geochronological data (e.g. Assis, 2008, 2011; Miguel Jr.,
2011) reinterprets some units and definition of others, such as the Aragão and Flor da Mata Granites, both belonging to the intrusive suite of Teles Pires Granite, Type 1 (TP1) as proposed by Paes de Barros (2007), and also the Pé Quente Intrusive Suite, granodiorite suite and União do Norte porphyry not recognized in previous works.

The Nhandu Granite was defined as a suite composed of rocks metaluminous to peraluminous, alkali-calcic to calc-alkaline, sub-alkaline, medium $\mathrm{K}$ and riched in $\mathrm{FeO}_{\text {total }}$, represented by monzogranite and syenogranite magnetite-biotite with calcalkaline affinity, and diorite to quartz-monzodiorite enclaves, in addition to subordinate sub-volcanic granites, granophyre and fine syenite quartz (Moreton \& Martins, 2005; Souza et al., 2005; Paes de Barros, 2007). Abram \& Silva (2008) interpret the tectonic setting as post-collisional to intra-plate unlike Paes de Barros (2007) who reports a geochemical trend of granitoids of magmatic arc to intra-plate granites. In addition to hosting primary gold mineralization (e.g. Natal and Trairão mines), this suite commonly shows evidence of potassic alteration with microcline, accompanied by precipitation of sulfides and magnetite.

Moura (1998) defined the Matupá Batholith and Moreton \& Martins (2000), based on petrographic data defined the Matupá Intrusive Suite, which includes the namesake batholith and several other granitic facies. Souza et al. (2005), maintaining the same terminology, described in detail four facies, which generally consist of granites, monzogranites, monzodiorites and monzonites. The Serrinha gold deposit, the main deposit correlated with this unit, is hosted by the Matupá Granite (Moura et al., 2006).

According to Souza et al. (2005), this suite is correlated to the Parauari Intrusive Suite of the Tapajós region, interpreted by Vasquez et al. (2002) as a result of a post-orogenic calc-alkaline magmatic event.

The Flor da Serra Intrusive Suite comprises gabbro dikes, gabbro-diorites, diorites, and monzo-gabbro and monzodiorites that display geochemical characteristics of both continental intraplate tholeiites and of the series of calc-alkaline volcanic arcs. (Moura \& Botelho, 2002; Souza et al., 2005). This suite intrudes the Matupá Intrusive Suite, with which displays diffuse or tectonic contacts.

Oliveira \& Albuquerque (2003) defined the Juruena Intrusive Suite as a suite of non-deformed and non-magnetic granitic rocks, with calc-alkaline affinity. Souza et al. (2005) used the same terminology to describe the unit as batholiths clumped together and amalgamated, distributed in the NW direction and composed of biotite-granites, with subordinate monzogranites, granodiorites 


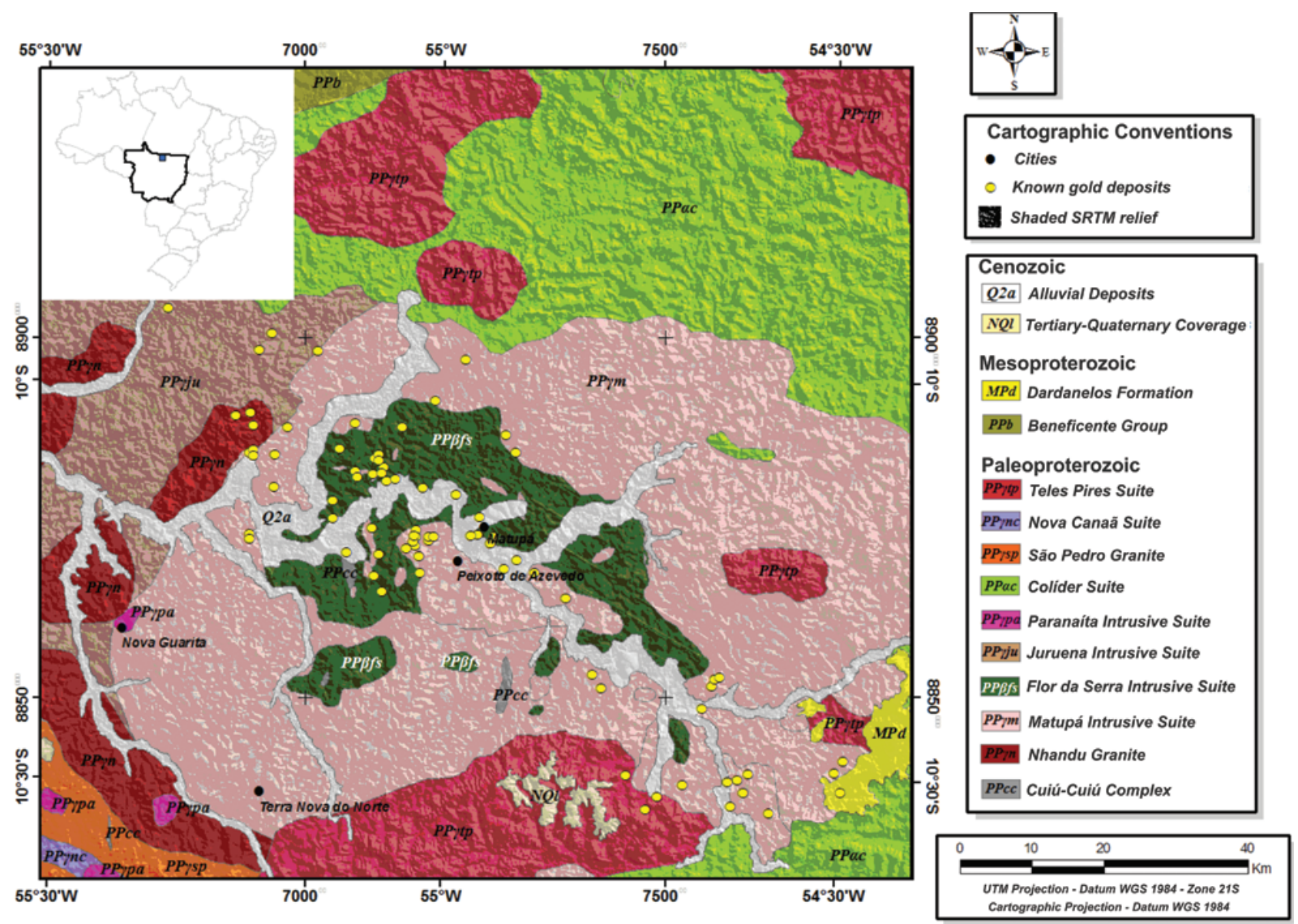

Figure 1 - Regional geological map of the study area (compilation from Rizzoto et al., 2004 and Moreton \& Martins, 2005).

and monzonites. According to these authors, the Paranaíta Intrusive Suite consists of monzonites, monzogranites and granites, being common the occurrence of mafic enclaves. Souza et al. (2005) describe the contact relationship of this unit as intrusive with the Juruena Suite and Bacaeri-Mogno Complex, locally tectonic with the São Pedro Granite, Colíder Suite and Juruena Intrusive Suite. Also it is locally observed that these rocks are involved by the Nhandu Granite and encompassing the mega-xenolites of the basement.

The metallogenetic potential of this unit is evidenced by the large number of primary gold deposits in quartz veins embedded in granitic intrusions and secondary gold located on the edges of these intrusions. The high concentration of oxidized facies, magnetite rich, demonstrates a hydrous magma with high oxygen fugacity and rich in gold and sulphides (Souza et al., 2005).

The Colíder Suite is represented by a wide variety of subvolcanic, volcanic, pyroclastic and epiclastic rocks of intermediate to acid composition (Souza et al., 2005; Silva \& Abram, 2008). It is correlated to the Juruena Magmatic Arc., aged from 1.85 to $1.75 \mathrm{Ga}$., which includes volcanic rocks of calc-alkaline nature of acidic to intermediate composition whose evolution is linked to the granitic Paranaíta, Juruena and Nhandu suites (Souza et al., 2005).

The São Pedro Granite composition rangers from syenogranite to biotite-monzogranites with subordinate granodiorites, tonalites, monzodiorites and alkali-granites. It is anisotropic, sigmoidal looking and syn-kinematic with NW shear zones, while quartz-diorite, quartz-monzonite and diorite enclaves are common, in addition to the supra crustal granulitic rocks (Moreton \& Martins, 2005; Souza et al., 2005). These granite were metamorphosed in medium amphibolite facies, with retro-metamorphic greenschist facies, and primary igneous structures also occur in non-deformed portions. It also has intrusive and tectonic contacts with the Victory, Nova Canaã Suites and the São Romão Granite unit.

The Nova Canaã Suite consists of a set of intrusive, plutonic and sub-volcanic bodies of elliptical geometry, forming batholiths, stocks and apophyses, from meso to epizonal, elongated and concordant to sub-concordant with extensive NW shear zones (Moreton \& Martins, 2005; Souza et al., 2005). The suite 
was divided into four facies, composed mainly of monzogranites, syenogranites and granites.

The Teles Pires Suite comprises an association of plutonic and sub-volcanic rocks, consisting of granite biotites and reddish porphyritic granites with presence of rapakivi and antirapakivi textures (Moreton \& Martins, 2005). Paes de Barros (2007) compartmentalizes the Teles Pires Volcanic-Plutonic Suite in: (i) Teles Pires volcanic, consisting of lava flows from felsic to intermediate, (ii) Braço Sul tuffs, represented by pyroclastic rocks, (iii) Braço Sul sediments, containing quartzites, arcosean sandstones and lytic greywackes; and (iv) Teles Pires type granites. Abram \& Silva (2008), based on geochronological and isotopic data, as well as the geochemical signature that points to A-type granite, interpret the unit as indicative of an extensional episode, post-collisional, between $1.78 \mathrm{Ga}$ and $1.76 \mathrm{Ga}$, which generates mantle magma with strong crustal contamination.

\section{MAGNETOMETRY AND GAMMA-RAY SPECTROMETRY Magnetometry}

Magnetic surveys identify rocks rich in ferromagnetic minerals such as magnetite, ilmenite and pyrrhotite, as a result of magnetic susceptibility contrasts with the immediate host rocks. Thus, contour maps of magnetic anomalies are often used to delineate contacts and geological structures. These maps show signals with large amplitude variation, reflecting sources within distinct crustal levels, with different geometry and magnetic susceptibility contrasts. Additionally, the shape of the magnetic anomaly depends on both the induced and remnant magnetization, making difficult the magnetic interpretation from the original data only. Thus, enhancement methods based on the directional derivatives of the magnetic field are commonly used to overcome these difficulties, thus facilitating the interpretation.

Considering only the induced magnetization, reducing to pole technique (RTP) allows anomalies to be located directly on the sources, minimizing the effects of magnetic inclination (Baranov, 1957). However, traditionally, reduction to pole technique appears to be quite unstable at lower latitudes (between $-20^{\circ}$ and $+20^{\circ}, \mathrm{Li}, 2008$ ), since both the real and the imaginary parts in the denominator of the RTP filter equation are close to zero (e.g. $L i, 2008)$.

Among the enhancement techniques commonly applied to potential field data are: analytic signal amplitude (ASA) (Nabighian, 1972, 1974; Roest et al., 1992), total horizontal derivative (THDR) (Cordell \& Grauch, 1985), inclination of the analytic signal (ISA) (Miller \& Singh, 1994), total horizontal derivative of total derivative (TDR-THDR) (Verduzco et al., 2004), Theta map (Wijns et al., 2005), TDX (Cooper \& Cowan, 2006) and total derivative of total horizontal derivative (THDR-TDR) (Ferreira et al., 2010).

Nabighian $(1972,1974)$ applied the concept of analytic signal amplitude to the potential field data derived from two-dimensional models. The concept has been extended to 3D bodies by Roest et al. (1992), in order to estimate the depth of the magnetic sources. However, despite the good ASA positioning of the anomalies on the sources, the method depends on the magnetic tilt (Li, 2006). In addition, the ASA is attenuated as the source deepens.

The THDR, according to Cordell \& Grauch (1985), has the property of enhancing the edges (maximum) and the centers (minimum) of magnetic sources, while the amplitudes are gradually attenuated with the depth of the models, such as in the ASA.

The TDR, introduced by Miller \& Singh (1994), main attributes are to equalize the amplitudes, to position the maximum over the center of the sources independently of source depths. However, as reported by Cowan \& Cooper (2008), this method does not detect the edges.

The TDR-THDR, defined by Verduzco et al. (2004), is efficient for lineament qualitative interpretation, since it is independent of the inclination and intensity of the magnetic gradient, and enhances and centralizes the maximum amplitudes over the sources edges. However, despite highlighting the source edges, the signals are attenuated as depth increases.

In the Theta map method (Wijns et al., 2005) and TDX (Cowan $\&$ Cooper, 2006) the amplitudes are equalized over the source edges, through the minimum and maximum, respectively. However, for deep sources, signals move away from the edges.

The THDR-TDR proposed by Ferreira et al. (2010) is similar to the Theta map and TDX methods, since it equalizes the signal amplitudes over the source edges. However, unlike these methods, its signals are confined to the sources, even the deeper ones, revealing itself as a more appropriate method for qualitative interpretation of potential field data.

Thus, synthetic gradients from magnetized bodies with known geometry, especially the ones from prismatic models due to their approximation to geological structures, are essential tools in the evaluation of enhancement methods (Guptasarma \& Singh, 2001). Thus, theoretical models such as the one proposed by Bongiolo (2011) help (i) in the analysis of the magnetic field behavior in areas with different latitudes, since the entered parameters are known and controlled, and (ii) in the responses of various enhancement methods applied to real magnetic data. 


\section{Gamma-ray spectrometry}

The main sources of gamma radiation near the surface are the result of the disintegration of the series of potassium $\left({ }^{40} \mathrm{~K}\right)$, uranium $\left({ }^{238} \mathrm{U}\right)$ and thorium $\left({ }^{232} \mathrm{Th}\right)$. On the other hand, total radioactivity is the measurement of all gamma rays recorded by the gamma spectrometer at a higher energy window that corresponds to the total count channel (Grasty et al., 1985).

Most of gamma spectrometers measure the counts per second (cps) that originate from four channels, as follows: (i) total count (0.4-2.82 MeV), (ii) thorium equivalent (2.42-2.82 MeV centered on ${ }^{208} \mathrm{TI}$ ), (iii) uranium equivalent (1.66-1.86 centered on ${ }^{214} \mathrm{Bi}$ ), and (iv) potassium (1.36-1.56 MeV centered on ${ }^{40} \mathrm{~K}$ ). Through an appropriate calibration method such counts per second can be expressed as concentration units such as $\mathrm{K}(\%)$, eU (ppm) and eTh (ppm).

Average potassium existing in the upper crust is $2.32 \%$ or $0.61 \% \mathrm{~K}_{2} \mathrm{O}$ (Rudnick \& Gao, 2004). Thorium occurs in the upper crust at average of $10.5 \mathrm{ppm}$, whereas uranium average concentration is $2.7 \mathrm{ppm}$ (Rudnick \& Gao, 2004).

On the continental crust, potassium is found mainly in feldspars (orthoclase and microcline), followed by micas and some clay minerals formed during diagenesis or hydrothermal alteration. Uranium occurs mostly in the form of oxide $\left(\mathrm{UO}_{2}\right)$, silicates (e.g. zircon), and rocks as pegmatites, syenites, carbonatites, granites and some shales. On the other hand, thorium occurs in minerals such as allanite, monazite, xenotime and zircon (Ulbrich et al., 2009). However, they may relatively easily replace each other in crystal structures. Thus, thorium and uranium-bearing minerals can appear in ETR, $\mathrm{Y}, \mathrm{Zr}$, $\mathrm{Hf}$ and others.

Dickson \& Scott (1997) showed that the concentration of radioelements in igneous rocks is related to their acidity, defined as the concentration of silica in the rock, and therefore, as $\mathrm{SiO}_{2}$ increases the radioelements also increase. Ulbrich et al. (2009) found that the number of mineral phases carrying thorium and uranium increases strongly on rocks formed in the later stages of magmatic differentiation.

Although each lithotype has a characteristic response to gamma-ray emission, a rock that has been subjected to certain weathering processes, the action of hydrothermal fluids or any other process to change its original features, creates a new set of gamma-ray spectrometry responses.

Thus, weathering processes affect the amount of radioelements in the rocks. In the case of chemical weathering, the effects depend on water acidity and salinity provided that these are sufficient to precipitate and remove the radioelements. Therefore, it is essential to distinguish in situ weathering products, which replace the upper portion of the source rock, from the products of the transport (physical) weathering that involves the mobilization of the material displaced by these processes (Gunn, 1998).

Potassium is extremely mobile, especially in tropical climates with heavy rainfall. Through chemical weathering, potassium hosting minerals particularly feldspars, under complete drainage of interstitial waters are transformed into kaolinite and, may change to smectite, under partial drainage conditions, with total or partial conservation of the element in the crystalline structure of clay minerals (Ulbrich et al., 2009).

Thorium-rich minerals exhibit low solubility and are stable during the chemical weathering process (except in acidic solutions). Thus, this element must be present in resistant minerals found in the soil and may also occur as ions adsorbed on oxides/ hydroxides of Al, Fe, Mn and Ti and structure of clay minerals, either in situ or colluvium materials (Dickson \& Scott, 1997; Ulbrich et al., 2009). Unlike uranium presents increased mobility, especially in oxidizing conditions at low temperature (Dickson \& Scott, 1997). The increased gamma-ray spectrometry signal of thorium and uranium in smoother topographic and drainage regions may suggest colluvial transport of more resistant minerals, as well as the newly-formed hosts of these elements (Ulbrich et al., 2009).

The hydrothermal fluids also change the original characteristics of the rocks, which may result mainly in potassium increase (e.g. Hoover \& Pierce, 1990; Dickson \& Scott, 1997; Fornazzari \& Ferreira Neto, 2003). Thus, ratios between gamma-ray spectrometry channels are used to identify rocks that have been subjected to these enrichment processes. The Th/K ratio (Ostrovsky, 1975; Pires, 1995) highlights the "antagonism" between the two elements; however, this ratio is not indicated to characterize granitic rocks, since thorium/potassium ratio is usually positive (Dickson $\&$ Scott, 1997). The parameter $F=K \times$ (eU/eTh) (Efimov, 1978 apud Gnojek \& Perichystal, 1985) highlights simultaneously K abundance and eU/eTh ratio, being widely used to distinguish areas of hydrothermal alteration from intensely weathered areas. In addition, Saunders et al. (1987) and Pires (1995) proposed the normalization of $\mathrm{K}$ and $\mathrm{U}$ by $\mathrm{Th}$, due to the fact that Th being less mobile, thus generating anomalous potassium $\left(K_{d}\right)$ and anomalous uranium $\left(U_{d}\right)$ parameters.

Thus, anomalies in the $\mathrm{K}$ channel can be identified in coppergold porphyry deposits and epithermal gold due to the presence of potassic alteration, with K-feldspar and/or sericitic alteration, associated with the presence of sericite and muscovite. However, the presence of a felsic intrusion can mask the deposits. In this 
case, the use of the $\mathrm{Th} / \mathrm{K}$ ratio can give a more accurate indication of the change extent, since thorium concentration is not increased during the mineralization process (e.g. Dickson \& Scott, 1997; Gunn, 1998).

\section{MATERIALS AND METHODS}

The geophysical database (gamma-ray spectrometry and magnetic) used is formed by projects implemented by Brazilian Geological Survey. In this study, the airborne geophysics database belonging to the Series 1000, 1052 - Juruena-Teles Pires Project, Phase 1 (CPRM, 1991) was used. These data are arranged according to N-S flight lines; 2,000 m apart, $60 \mathrm{~m}$ sampling interval, $150 \mathrm{~m}$ flight altitude and $36,300 \mathrm{~km}^{2}$ area coverage.

Through a technical cooperation agreement between Brazilian Geological Survey and the Geological Survey of Canada (Brazil Airborne Radiometric Mapping Project - BARMP, 1997), all airborne gamma-ray spectrometric data of Brazil were reprocessed and microleveled. Thus, counts per second (cps) original data were transformed to $\mathrm{CT}(\mu \mathrm{R} / \mathrm{h})$ and of $\mathrm{K}(\%)$, eU (ppm) and eTh (ppm) concentrations, via a retro-calibration process.

Residual airborne gamma-ray spectrometric and magnetic data were interpolated into a $500 \times 500$ meter regular grid $(1 / 4$ of the nominal line spacing of flight) using the method of minimum curvature (e.g. Briggs, 1974). This method generates a smoothed out surface with values that approximate the original data, being widely used for its computational efficiency and effectiveness. In the case of magnetic data, the method was applied through a bidirectional algorithm (GEOSOFT, 2011). Firstly, the data were interpolated along the flight lines and subsequently in the direction perpendicular thereto. The bidirectional algorithm is designed to interpolate data that have been acquired along approximately parallel flight lines, since they tend to enhance the features perpendicular to the survey lines.

The airborne magnetic data were originally available corrected for the IGRF and diurnal variation. However, some of the survey lines were deleted because they showed inconsistencies that could hamper the processing. These are: L1711E, L1791E, L2001E, L2021E, L2022E, L2051E, L2101E, L2141E, L2142E and L2511E. In addition, the magnetic data histogram was equalized so that the average remained near $0 \mathrm{nT}$. A $4000 \mathrm{~m}$ low-pass filter was applied to the database in order to contemplate the Nyquist frequency.

Through 3D theoretical models proposed by Bongiolo (2011) (Fig. 2), the geometric and magnetic parameters are shown in Tables 1 and 2, we sought to analyze the anomalous magnetic field behavior and enhancement methods performance in the study area - that is at low latitude - comparing the responses with anomalies derived from the same model positioned on the Earth's magnetic pole.

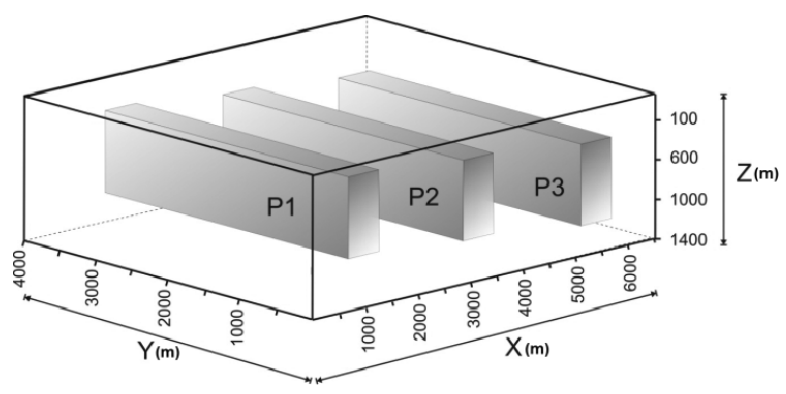

Figure 2 - 3D synthetic models (Bongiolo, 2011).

Table 1 - Geometrical parameters of the 3D theoretical models.

\begin{tabular}{|c|c|c|c|}
\hline Local & Prism P1 & Prism P2 & Prism P3 \\
\hline$X(m)$ & $500-1000$ & $3000-3500$ & $5500-6000$ \\
Y (m) & $500-3500$ & $500-3500$ & $500-3500$ \\
Z (m) & $100-1100$ & $200-1200$ & $300-1300$ \\
\hline
\end{tabular}

Table 2 - Magnetic parameters of the 3D theoretical models.

\begin{tabular}{|c|c|c|}
\hline Parameters & Alta Floresta & Pole \\
\hline Latitude & $-10^{\circ} 15^{\prime} 00^{\prime \prime} \mathrm{S}$ & $85^{\circ} 00^{\prime} 00^{\prime \prime} \mathrm{N}$ \\
Longitude & $-55^{\circ} 00^{\prime} 00^{\prime \prime} \mathrm{W}$ & $132^{\circ} 36^{\prime} 00^{\prime \prime} \mathrm{E}$ \\
Declination $\left(\mathrm{D}^{\circ}\right)$ & $-15.0^{\circ}$ & $0.0^{\circ}$ \\
Inclination $\left(\mathrm{I}^{\circ}\right)$ & $-2.0^{\circ}$ & $90.0^{\circ}$ \\
Magnitude $(\mathrm{T})$ & $26.297 \times 10^{-9}$ & $56.973 \times 10^{-9}$ \\
$\mathrm{Ji}(\mathrm{A} / \mathrm{m})$ & 0.57 & 1.25 \\
\hline
\end{tabular}

In the case of gamma-ray spectrometry data, which were already corrected by BARMP (1997), only the four channel histograms were equalized so that the minimum remained close to 0.01 counting unit (c.u.), in order to avoid the "K effect" (Ferreira et al., 2009) and other inconsistencies during processing. In addition, we applied a $4000 \mathrm{~m}$ low-pass filter to the database, thus contemplating the Nyquist frequency.

The main products used for the interpretation of geophysical data were (i) THDR-TDR, (ii) RGB composite of three vertical derivatives with distinct differentiation orders (R0,75 G1,00 $B 1,25)$ associated with SRTM image, (iii) RGB composite of gamma-ray spectrometry channels (K, eTh, eU), (iv) Fuzzy Clustering, and (v) gamma-ray spectrometry ratios.

The THDR-TDR method associates the attributes of both TDRTHDR methods enhancing equally the signals at the edges of the bodies regardless of their depth. Thus, the high gradients are interpreted as lineaments, which can later be associated with geological structures. 
The interpretation of surface lineaments from the magnetic data was also based on features highlighted by the magnetic gradient. The visual layout of the lineaments was made from the ternary composition of the distinct differentiation orders of the vertical derivative (R0,75 G1,00 B1,25).

The SRTM image was used only as a benchmark to check whether the lineaments already interpreted were correlated with the features highlighted by the relief. We opted to interpret the composition of vertical derivatives, since the magnetic data generate a synthetic relief based on physical characteristics of the subsurface materials while the SRTM image generates a synthetic relief from lighting which can be subject to considerable variations.

The Fuzzy Clustering consists of a system of unsupervised classification. Similar classes (fuzzy clusters) are grouped together according the statistical behavior of the data, without needing training points (e.g. Looney \& Yu, 2000; Lammoglia, 2006; Magalhães \& Souza Filho, 2012). The method was used in order to refine the geological interpretation to ensure careful individualization of the rocks found in the study area.

The gamma spectrometric ratios, widely used to enhance hydrothermalized and in potassium (or uranium) rich areas, consist in some cases of the simple relationship between their own basic channels (e.g. eTh/K and eU/K). However, in the $\mathrm{Kd}$ case occurs the normalization of potassium by thorium, since the latter is less mobile. This calculation is given by the equation:

$$
K_{d}=\left(K_{s}-K_{i}\right) / K_{i}
$$

where,

$$
K_{i}=\left(\text { average } K_{s} \text { /average } T h_{s}\right) \times T h_{s}
$$

where $K_{s}$ and $T h_{s}$ are the values measured in the surveys.

\section{RESULTS AND DISCUSSION \\ Magnetometry}

The prismatic model of Figure 2 and the parameters of Tables 1 and 2 were used to generate the magnetic field anomalous map. Subsequently, this map was reduced to the pole and the following enhancement methods were applied: (i) THDR; (ii) TDR; (iii) TDR-THDR and (iv) THDR-TDR. Based on the results of theoretical models (Fig. 3) the enhancement techniques do not displaced significantly the positioning of the anomalies related to the prisms in the anomalous field and in the reduced to the pole maps. However, for the study area, the magnetic declination generates artificial trends when the data are reduced to the pole (Fig. 3E, H, Kand $\mathrm{N}$ ), becoming, therefore, necessary to suppress these tendencies toward declination using a directional filter.
The Juruena-Teles Pires Project magnetic data (Phase 1) underwent the same procedures used for the synthetic models. Initially, the magnetic anomaly map (Fig. 4A) was reduced to the pole (Fig. 4B). This created, as for the theoretical data, trends in the direction of magnetic declination. To suppress these trends and also the noise caused by the influence of shallow sources, the following filters were applied: (i) space domain directional cosine toward the center to 350 and grade 1 (Fig. 4C) and (ii) upward continuation with $2000 \mathrm{~m}$ elevation (Fig. 5A). Then, the maps shown in Figure 5 were produced based on the same enhancement methods applied to the theoretical data (Fig. 3). Only the analytic signal amplitude (ASA) (Fig. 5B) was calculated from the anomalous magnetic field map not reduced to pole. This procedure was used because like the reduction to the pole filter this enhancement technique aims to plot the magnetic field as in the magnetic Earth's magnetic pole, transforming the dipoles in gradients that allow understanding the geometry of the source. Therefore, it makes no sense to calculate the ASA from the reduced to the pole map.

Although consisting of a semi-quantitative technique, the Euler solutions (Thompson, 1982) were superimposed on all maps discussed below, in order to evaluate only the positioning of the sources (dike model, $\mathrm{Sl}=1$ ) relating to the responses of the magnetic enhancements and to check trending, thereby assisting the interpretation of lineaments.

On the analytic signal amplitude map (ASA, Fig. 5B), Euler solutions are positioned on both maximum and intermediate amplitudes, suggesting that the signal attenuation is due to the source depths, assuming that magnetic susceptibility contrasts, geometry and magnetization are constant (Ferreira et al., 2010).

The total horizontal derivative (THDR, Fig. 5C) shows that EuIer solutions practically follow the trends of maximum anomalies. However, they also positioned themselves on intermediate ranges, under the same assumptions about signal attenuation and source depth.

The tilt derivative (TDR, Fig. 5D) indicates that the maximum, reflecting the body axes, do not coincide with the EuIer solution trends, which represent the source edges and position themselves in the anomaly gradients. Therefore, Figure 5D demonstrates that TDR is not an edge detecting method. Although, as expected, some maximum values coincide with Euler solutions trends, the TDR-THDR method (Fig. 5E) shows a series of ellipsoidal and/or circular artificial trends, reflecting interfering sources. However, as with the ASA (Fig. 5B) and THDR (Fig. 5C) techniques, the TDR-THDR amplitudes attenuate with source depth. 


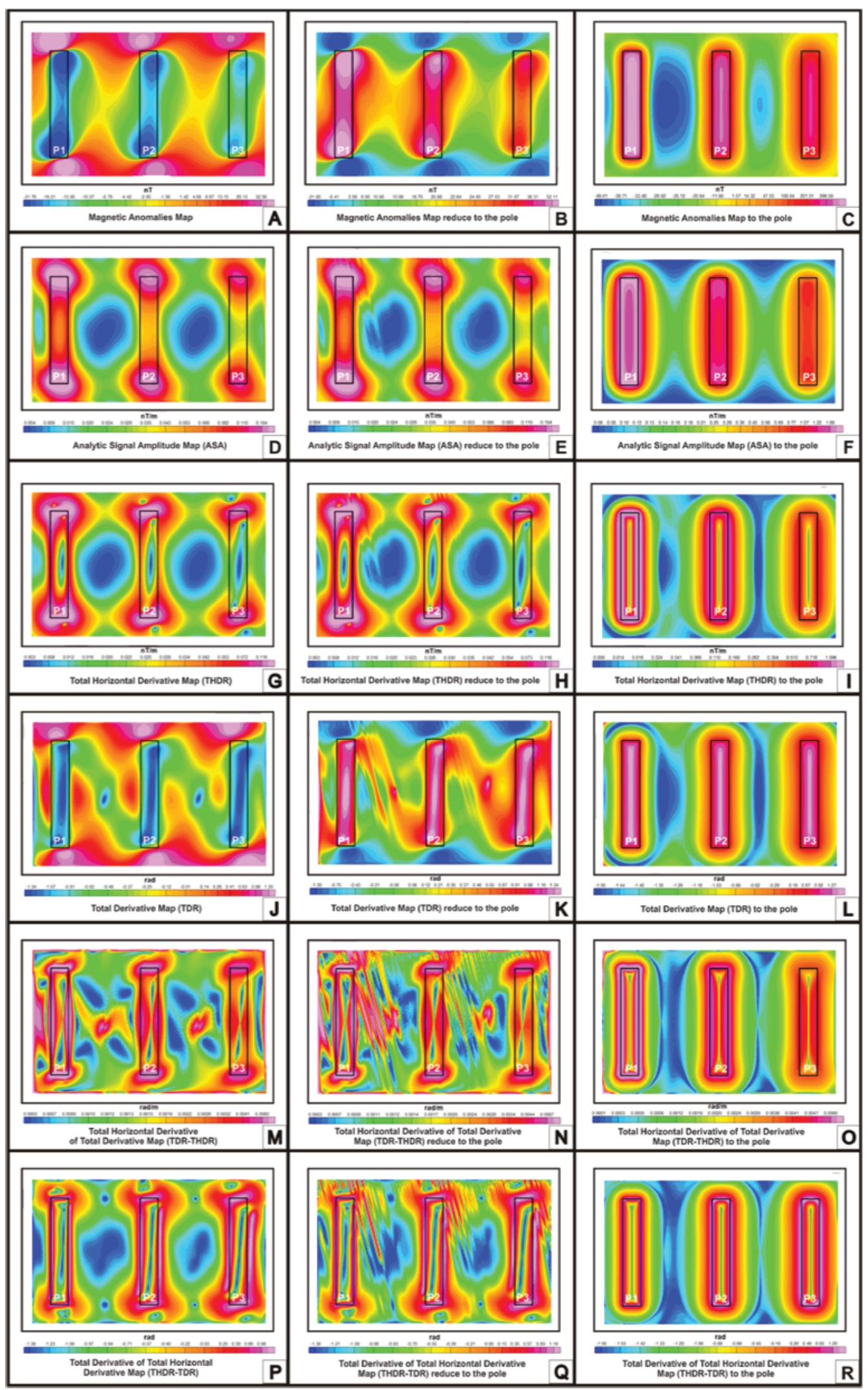

Figure 3 - Magnetic data enhancement methods applied to the theoretical models. 


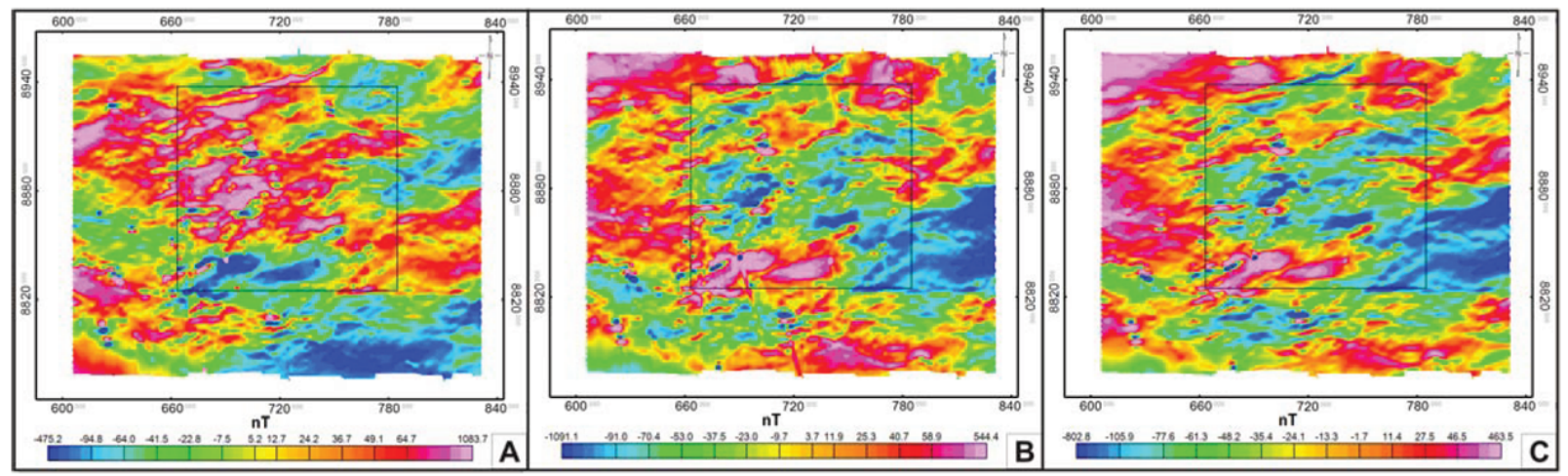

Figure 4 - Magnetic field maps (A) anomalous, (B) reduced to the pole (C) reduced to the pole and corrected using the cosine-directional filter. Study area highlighted in black (data from the Juruena-Teles Pires Project, phase 1, CPRM, 1991).

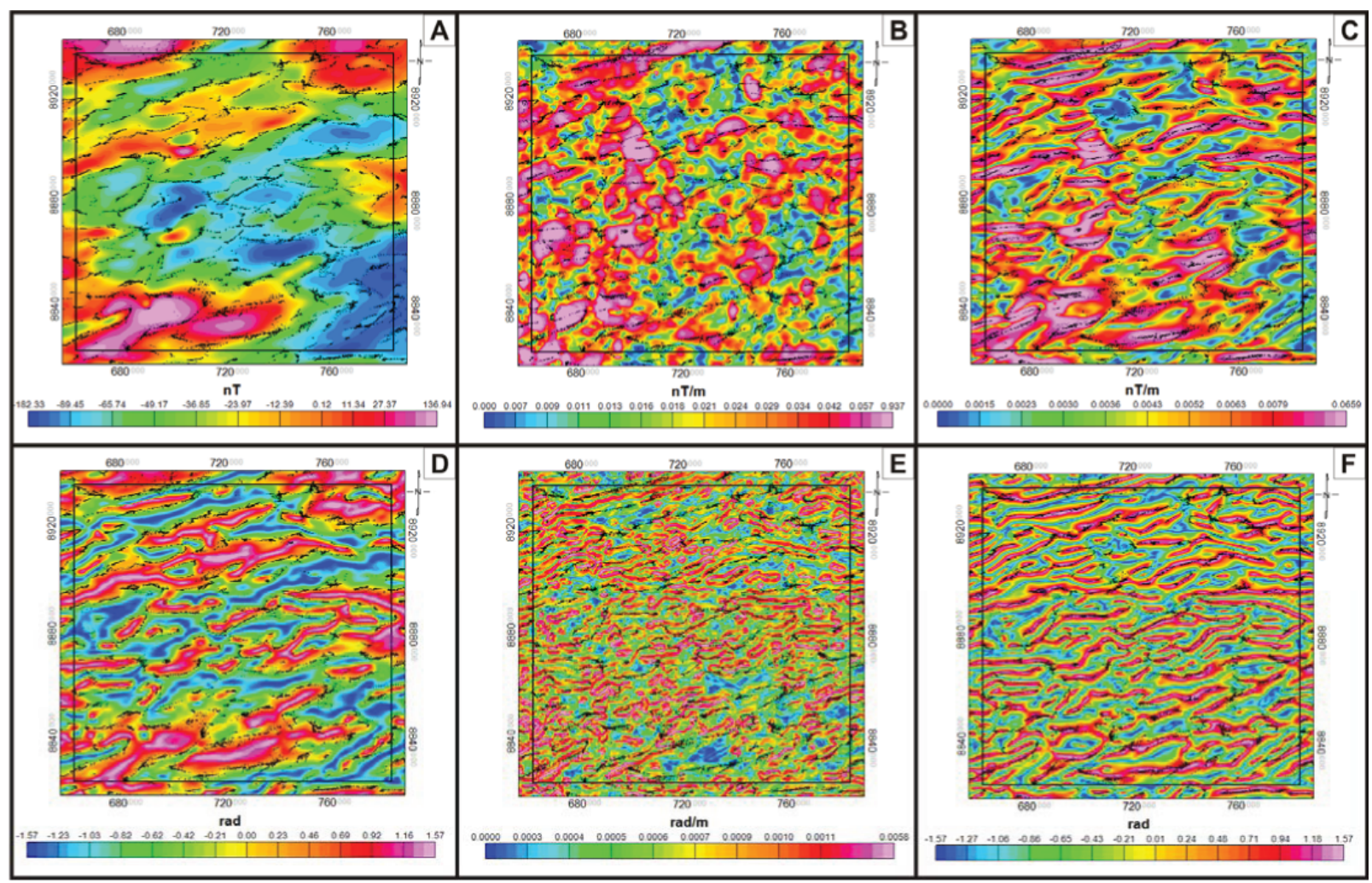

Figure 5 - Enhancement methods applied to the magnetic data (A) Upward continuation (2000 m), (B) ASA, (C) THDR, (D) TDR, (E) TDR-THDR and (F) THDR-TDR. The black dots represent the Euler solution $(S \mid=1)$ (data from the Juruena-Teles Pires, Project, phase 1, CPRM, 1991).

The THDR-TDR method (Fig. 5F) equalizes signal amplitudes and displays the maximum on the source edges, which coincide with the Euler solution trends, proving to be an appropriate method for interpreting qualitative data of potential fields.

Thus, the study area lineaments enhanced by magnetometry were interpreted (Fig. 6A) from the THDR-TDR map (Fig. 5F). As the anomalous magnetic field data were continued upwards (2000 $\mathrm{m}$ ) before generating the THDR-TDR map, the interpreted lineaments reflect deep to intermediate crustal levels since shallow sources were suppressed by the upward continuation filter.

Additionally, surface lineaments (Fig. 6B) were interpreted from the RGB composition of three vertical derivatives with distinct differentiation orders (R0,75 G1,00 B1,25) applied to the anomalous magnetic field map (Fig. 4A) together with the shaded SRTM image, in order to correlate them with the lineaments enhanced by magnetometry seen in the THDR-TDR map (Fig. 5F). 

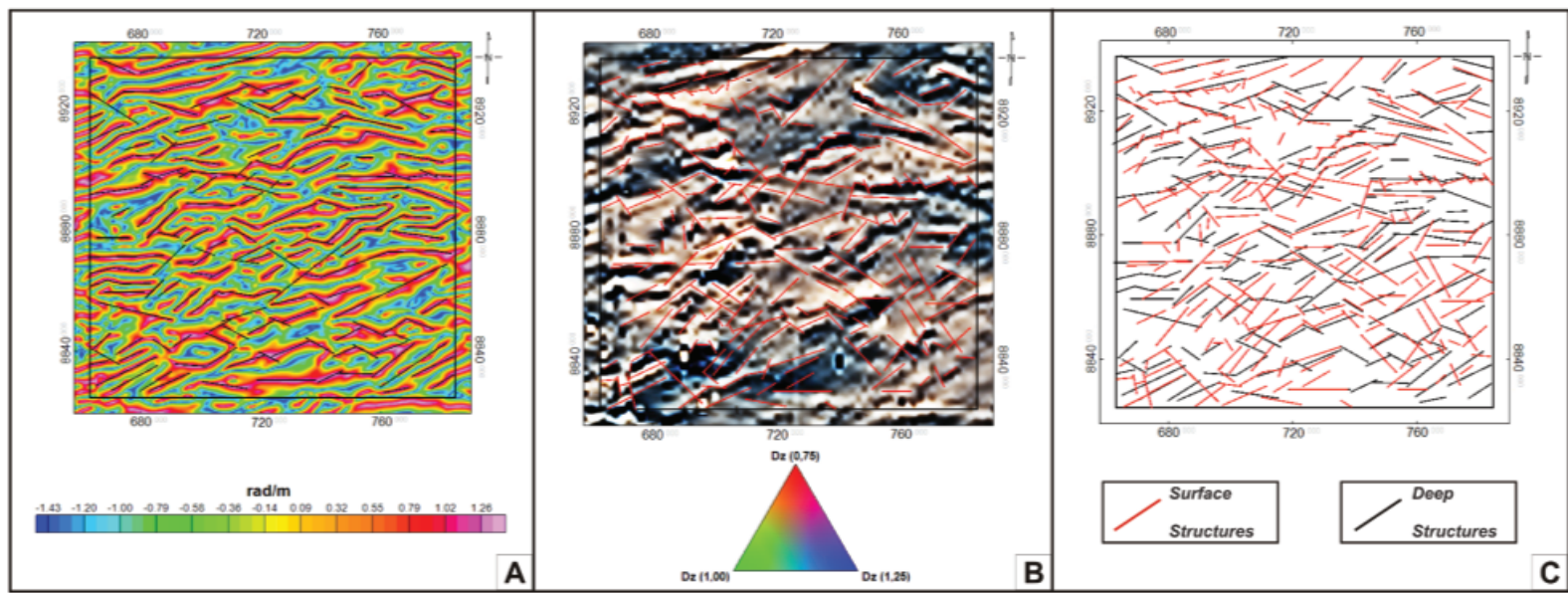

Figure 6 - Lineament interpretation from the enhancement methods: (A) THDR-TDR and (B) RGB of the vertical derivatives. (C) comparison between deep and superficial lineaments.

Figure $6 \mathrm{C}$ shows that many intermediate depth lineaments (Fig. 6A) superimpose surface ones (Fig. 6B), therefore penetrative, that may have served as a conduct for hydrothermal fluids percolation, favoring sulfides deposition and consequently, formation of gold deposits.

The interpreted lineaments (Fig. 6A) show structural features especially trending E-W and NE-SW directions. Thus, as already stated by Paes de Barros (1994) and Parro (1998), the $\mathrm{E}-\mathrm{W}$ structures are the oldest and difficult to identify on the surface due to their deeper roots. The NE-SW structures are coupled to E-W structures through sinistral kinematics. Moreover, the predominance of E-W lineaments strongly approximates to the craton compartmenting model proposed by Tassinari \& Macambira (1999).

On the other hand, the more recent NW-SE, N-S and NE-SW structures, described by Parro (1998) and present in the compartmenting model proposed by Santos et al. (2000) and Santos (2003) (mainly NW-SE), were not identified in the study area through the magnetic data, at least not with the same expression described by these authors. This is possibly due to the predominance of the signal of deeper sources over the signal of shallow ones. Moreover, there is the possibility that the regional structure proposed by several authors does not explain adequately the entire Alta Floresta Project area (shales São João da Barra, Alta Floresta, Ilha 24 de Maio and Vila Guarita) (Souza et al., 2005).

Thus, for example, Miguel Jr. (2011) suggests that distinct structural frameworks resulting from different tectonic events in AFGP areas are suitable alternatives to models that attempt to explain the structural complexity of the province based on the same kinematic arrangement. It should also be taken into consideration that the gold deposits associated with AFGP granitic rocks were formed in multiple stages between $1.96 \mathrm{Ga}$ (e.g. Novo Mundo and Pé Quente) and $1.82 \mathrm{Ga}$ (e.g. Serrinha of Matupá). Possibly, in the interval of $140 \mathrm{Myr}$, distinct tectonic regimes and/or reactivations must have influenced the structural complexity of the AFGP.

\section{Gamma-ray spectrometry}

The maps of $\mathrm{K}$ (Fig. 7A), eTh (Fig. 7B) and eU (Fig. 7C) channels were mainly used to generate the RGB ternary composition and the Fuzzy Clustering product, which along with the CT channel (Fig. 7D) allowed identify the litho-geophysical domains, each domain having different combinations of $\mathrm{K}$, eU and eTh contents.

The ratio maps were used to determine possible zones with hydrothermal alterations. The ratios that show anomalous accumulation of potassium such as, $\mathrm{K}_{d}$ (Fig. 8A), eTh/K (Fig. 8B), eU/K (Fig. 8C) and parameter F (Fig. 8D) were used in the study, aiming to map hydrothermal alteration of potassic and sericitic types, which are proved to be associated with gold mineralization in the region (e.g. Assis, 2011; Xavier et al., 2011).

In these maps, the higher gradients outline potassium-rich granitic rocks abundant in the area (e.g. Aragão, Flor da Mata and Novo Mundo Granites). On the other hand, hydrothermalized areas that should be enhanced for this reasons, present themselves as very large areas, mingling with the mineral contents of the rocks found in the region. However, especially in $\mathrm{K}_{d}$ (Fig. 8A) and eTh/K (Fig. 8B) maps, we observe well-defined linear areas, sometimes spatially correlated with lineaments defined from the magnetic data. Therefore, these linear zones could represent the expression of hydrothermal alteration zones that are rich in potassium lined up along the faults. 


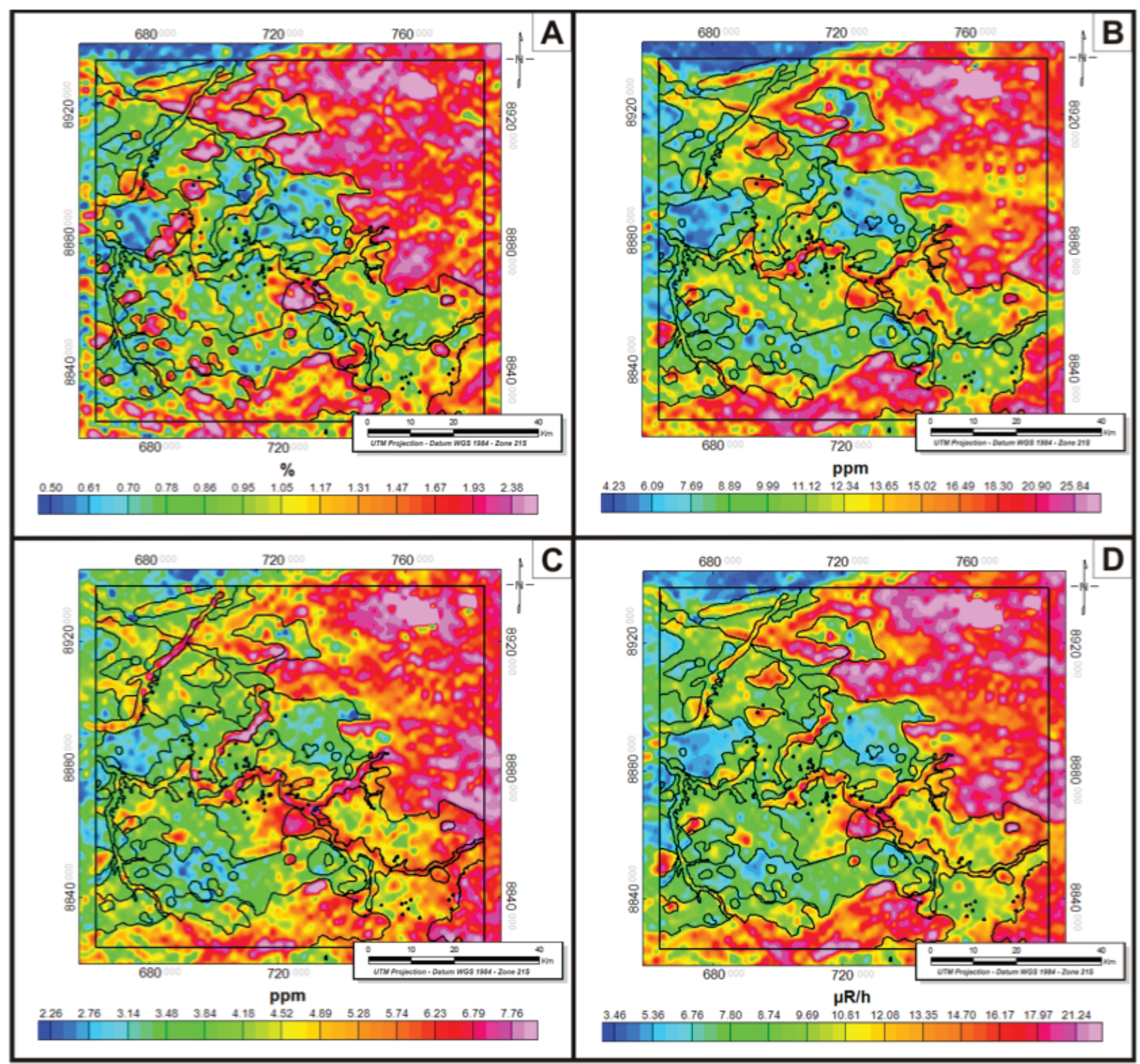

Figure 7 - Gamma-ray spectrometry maps: (A) K channel, (B) eTh channel, (C) eU channel and (D) CT channel. The black dots represent the known gold deposits and the polygons the identified litho-geophysical domains.

The individual domains can be correlated to previously described and mapped lithological units or represent facies and compositional variations not yet identified in certain units. Thus, the boundaries between the domains may not correspond to transitions between different lithostratigraphic units, but to variations within the same unit.

The correlation between the litho-geophysical domains and geological units was based on the responses exhibited by the gamma-ray spectrometry products and data from several different mapping studies conducted in the region. However, due to the low resolution data, some units described in previous studies do not present a typical signature enabling their identification. Thus, some geological units previously identified in greater detail in recent works (e.g. Assis, 2011; Miguel Jr., 2011) were not included in this work.

Thus, the litho-types were identified through qualitative interpretation of RGB gamma-ray spectrometry channels (Fig. 9A) together with the Fuzzy clustering product (Fig. 9B) and the CT channel, resulting in the litho-geophysical domain map (Fig. 9C). In the final product (Fig. 9D), some areas were grouped into one 


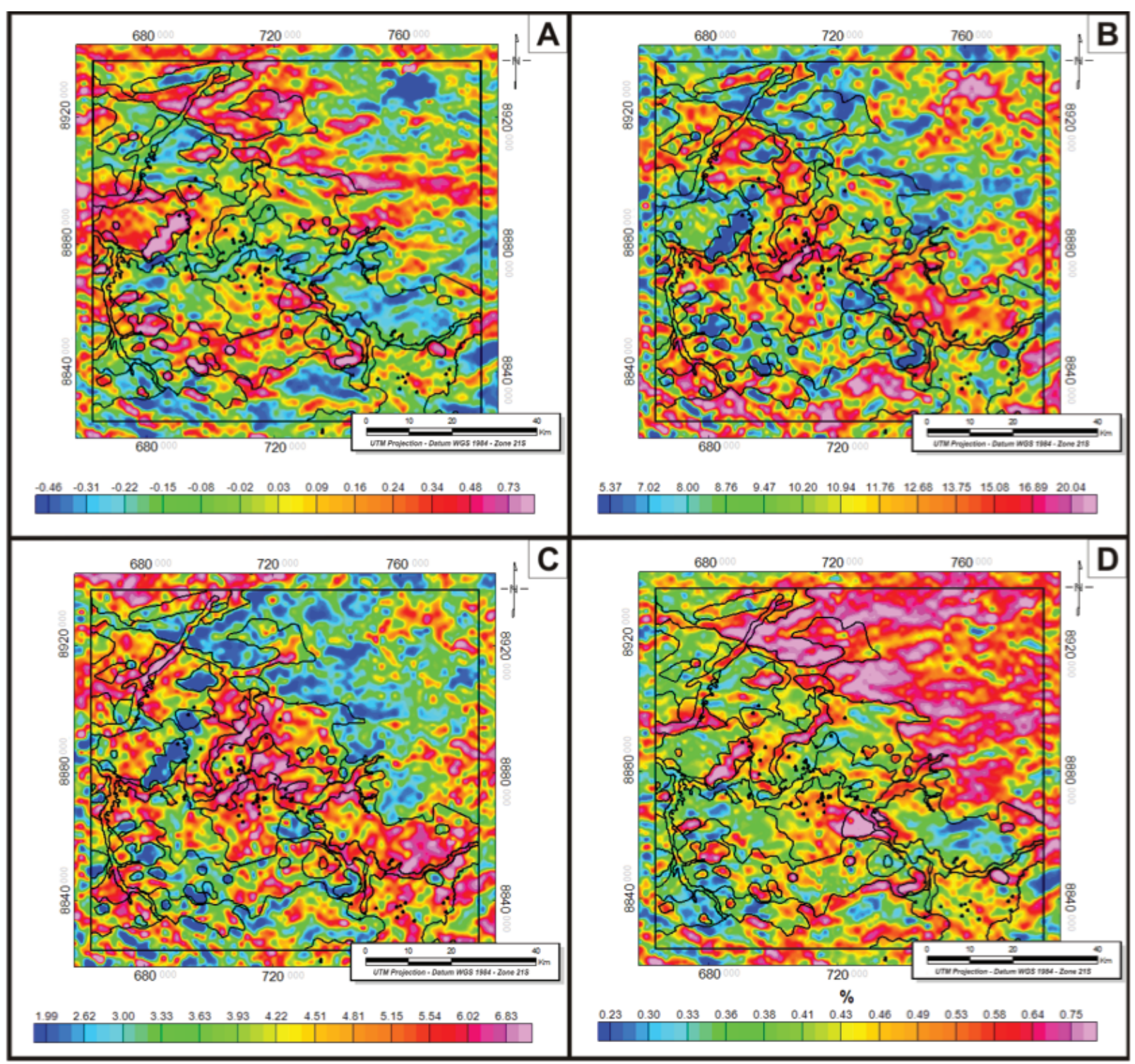

Figure 8 - Maps of the gamma-ray spectrometry ratios: (A) $K_{d}$, (B) eTh/K, (C) eU/K and (D) F parameter. The black dots represent the known gold deposits and the polygons. The identified litho-geophysical domains.

geological unit considering the similar gamma-ray spectrometry pattern (e.g. domains 1, 15 and 21 were interpreted as part of Matupá Intrusive Suite).

Due to contradictions regarding the origin of the basement in this portion of the AFGP, we chose to identify only the spatial area, without conclusively correlating it either with the Cuiú-Cuiú or Xingu Complex. The devastated relief was the main attribute used to define the occurrence area, as seen on the SRTM image, since either on the RGB composite or Fuzzy Clustering product the $\mathrm{K}$, eU and eTh variation alone did not characterize this unit.

The basement granitoids were correlated to the darker areas of the RGB map (K-eTh-eU) since their compositional characteristics reflect low levels of the three radioactive elements (e.g. quartzdiorites, tonalites and granodiorites).

The Colíder Suite area defined by Moreton \& Martins (2005), Souza et al. (2005) and Silva \& Abram (2008) was interpreted as part of the Volcano-Plutonic Teles Pires Suite, as proposed by Pinho (2002) and Paes de Barros (2007). However, it was not possible to identify (with the exception of the pyroclastic Braço Sul Tuffs, in the northern study area) the partitioning proposed by Paes de Barros (2007); therefore, they were grouped into a single unit. 


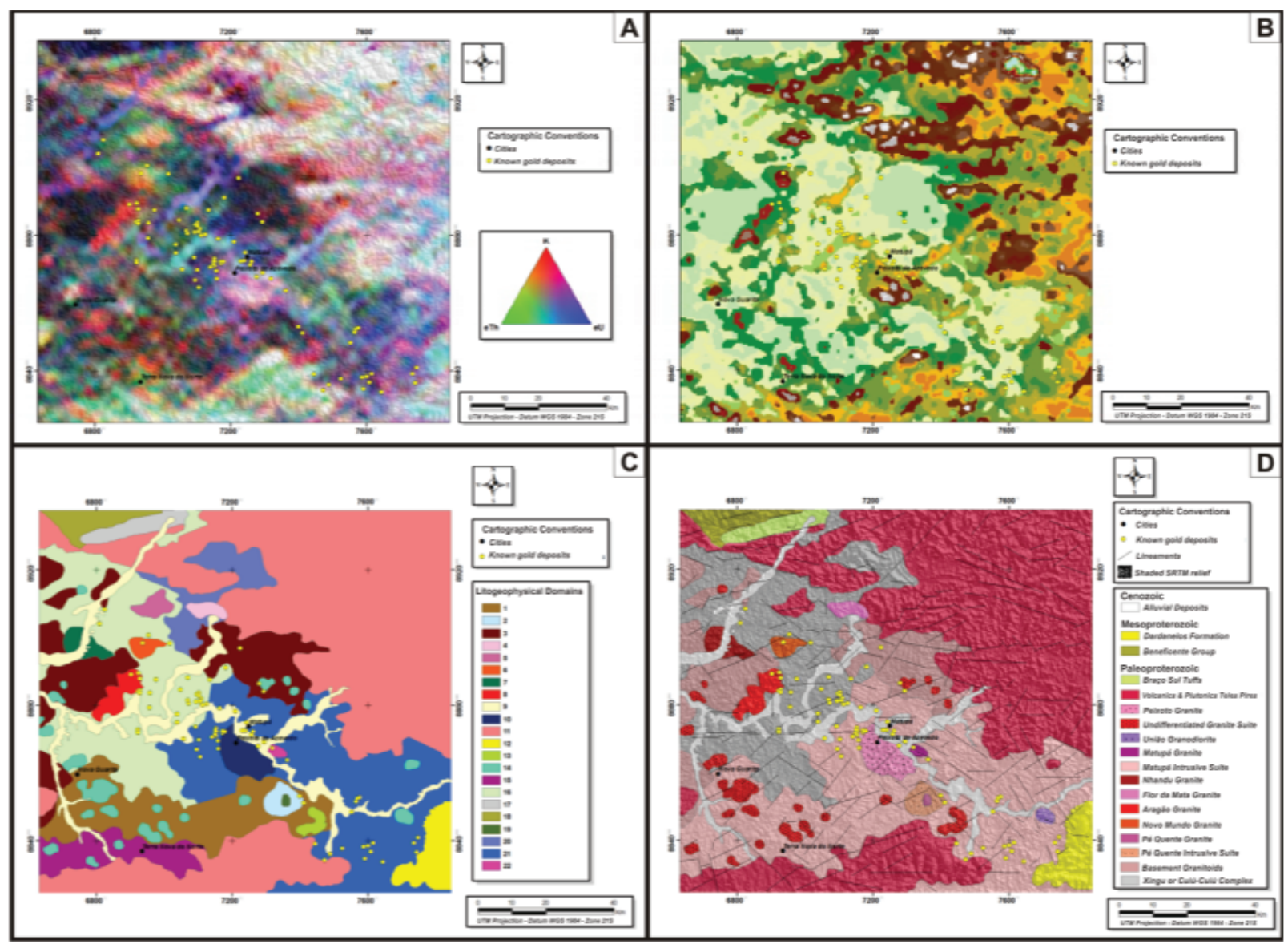

Figure 9 - Products used to interpret the litho-geophysical domains and the geological units, and the final (A) RGB and (B) Fuzzy Clustering (C) Litho-geophysical domains and (D) Final geological map.

The Matupá Granite (Paes de Barros, 2007; Miguel Jr., 2011) presents itself as an elongated body to the south of Matupá city. According to Miguel Jr. (2011) the intrusive bodies in the Granitoids of the basement (central portion of the map) are correlated with this unit. However, from the geophysical signature view point, these bodies have a higher correlation with the Undifferentiated Granitic Suite (defined in this paper), due to its high response to $\mathrm{K}$, and were therefore, grouped under that name.

The boundaries of Juruena Intrusive Suite, Paranaíta Intrusive Suite, São Pedro Granite and Nova Canaã Suite were not recognized as in the works of Moreton \& Martins (2005), Souza et al. (2005) and Silva \& Abram (2008) while the area corresponding to these units were interpreted as belonging to the Teles Pires Volcano-Plutonic Suite. The Nhandu Granite had its occurrence area limited to a single body, resembling the interpretation of Paes de Barros (2007) and Miguel Jr. (2011).

The boundaries of the Aragão, Flor da Mata, Peixoto and Novo Mundo granites, already recognized elsewhere (Paes de Barros,
2007; Miguel Jr., 2011), were slightly modified according to their response to $\mathrm{K}$, eTh and eU contents. Additionally, units like the granodioritic suite, the Pé Quente Suite and Pé Quente Intrusive Suite (Assis, 2011; Miguel Jr., 2011), could also be identified from the RGB composite and Fuzzy Clustering product.

However, due to the low resolution of the data, units that were previously identified in greater detail in the southeastern portion of the study area (e.g. União do Norte Porphyry, Granitic Suite, Volcano-clastic unit) (Assis, 2011; Miguel Jr., 2011) were not identified in the products generated in this work.

\section{CONCLUSIONS}

The products generated from the magnetic data processing were satisfactory for structural interpretation, despite the limitations of the reduction to the pole technique at low latitudes. The artificial trends generated by the magnetic declination were removed using a directional filter, eliminating trends that may interfere with the use of enhancement methods. 
The total derivative of total horizontal derivative (THDR-TDR) proved to be the most suitable enhancement method for interpretation of lineaments, since the amplitude of the signal does not vary with depth. Thus, both the deeper and intermediate crustal lineaments could be contemplated during interpretation. The shallower lineaments were identified in the RGB product of vertical derivatives with distinct differentiation orders together with the SRTM image.

The comparison of lineaments main directions (Fig. 6C) interpreted from enhancement THDR-TDR and from the RGB composition shows that NW-SE and NE-SW lineaments are more frequent at shallow crustal levels, corroborating the hypothesis that they represent younger tectonic events in this portion of the AFGP. Furthermore, many lineaments show some correlation with the different analyzed crustal levels. However, there is still lack of evidence to conclude whether these lineaments reflect geological structures themselves and whether these are the result of multiple reactivations that allowed their expression in the surface or, as they formed, they simultaneously affected various crustal levels.

Despite the low density of the airborne survey data, some lithological units that do not appear in previous works have been identified here, such as the Undifferentiated Granitic Suite, which was individualized according to its relatively high response to $\mathrm{K}$, resembling the response of other granitic rocks from the region. Thus, these granitic rocks can be associated to the Matupá Intrusive Suite unit (Moreton \& Martins, 2000; Souza et al., 2005), or represent a new geological unit, not yet characterized, with metallogenetic potential since mineralization in the AFGP occur mostly associated with granitic rocks.

\section{REFERENCES}

ABREU MC. 2004. Alteração hidrotermal e mineralização aurífera do depósito de Novo Mundo, região de Teles Pires - Peixoto de Azevedo, Província de Alta Floresta (MT). Trabalho de Conclusão de Curso, Instituto de Geociências, Universidade Estadual de Campinas, Campinas, $29 \mathrm{pp}$.

ASSIS RR. 2008. Contexto geológico e associação paragenética das mineralizações auríferas de União do Norte, região de Peixoto de Azevedo, Província de Alta Floresta (MT). Final graduation paper Instituto de Geociências, Universidade Estadual de Campinas, Campinas, $81 \mathrm{pp}$.

ASSIS RR. 2011. Depósitos auríferos associados ao magmatismo granítico do setor leste da Província de Alta Floresta (MT), Cráton Amazônico: tipologia das mineralizações, modelos genéticos e implicações prospectivas. Master Dissertation - Instituto de Geociências, Universidade Estadual de Campinas, Campinas, 462 pp.
BARANOV V. 1957. A new method for interpretation of aeromagnetic maps: Pseudo-gravimetric anomalies. Geophysics, 22: 359-383.

BARBUENA D. 2009. Elementos-traço em sulfetos de depósitos auríferos hidrotermais da Província de Alta Floresta (Mato Grosso). Relatório Final PIBIC/CNPq, Instituto de Geociências, Universidade Estadual de Campinas, $20 \mathrm{p}$.

BARMP. 1997. Brazil Airborne Radiometric Mapping Project. Paterson, Grant \& Watson Limited (PGW), Serviço Geológico do Brasil (CPRM) and Geological Survey of Canada (GSC), Technical Report and Survey Atlas, Ottawa, Canada. 18 pp.

BIZOTTO AC. 2004. Mineralizações auríferas na região de Teles Pires - Peixoto de Azevedo (Mato Grosso), Província de Alta Floresta: 0 Depósito de Santa Helena. Final graduation paper, Instituto de Geociências, Universidade Estadual de Campinas, Campinas, 38 p.

BONGIOLO ABS. 2011. Contribuição ao estudo da Bacia do Amazonas e seu embasamento através de magnetometria e gravimetria. Doctorate thesis, Instituto de Geociências, Universidade Federal do Paraná, Curitiba. 290 pp.

BRIGGS IC. 1974. Machine contouring using minimum curvature. Geophysics, 39(1): 39-48.

COOPER GRJ \& COWAN DR. 2006. Enhancing potential field data using filters based on the local phase. Comput. Geosci., 32(10): 1585-1591.

COOPER GRJ \& COWAN DR. 2008. Edge enhancement of potential-field data using normalized statistics. Geophysics, 73(3): H1-H4.

CORDELL L \& GRAUNCH VJS. 1985. Mapping basement magnetization zones from aeromagnetic data in the San Juan Basin, New Mexico. In: HINZE WJ (Ed.). The Utility of Regional Gravity and Magnetic Anomalies Maps. Society of Exploration Geophysicists, 181-197.

CPRM. 1991. Projeto Juruena - Teles Pires, Fase 1, Levantamento e Processamento dos Dados. Secretaria Nacional de Minas e Metalurgia, Serviço Geológico do Brasil (CPRM), Relatório Final, 3 vol., Rio de Janeiro.

DICKSON BL \& SCOTT KM. 1997. Interpretation of aerial gamma-ray surveys - adding the geochemical factors. In: Airborne Magnetic and Radiometric Surveys, AGSO Journal of Australian Geology \& Geophysics, 17(2): 187-200.

FERREIRA FJF, FRUCHTING A, GUIMARÃES GB, ALVES LS, MARTIN VMO \& ULBRICH HH. 2009. Levantamentos gamaespectrométricos em granitos diferenciados II: 0 exemplo do Granito Joaquim Murtinho, Complexo Granítico Cunhaporanga, Paraná. Geologia USP. Série Científica, $9(1): 55-72$.

FERREIRA FJF, SOUZA J, BONGIOLO ABS, CASTRO LG \& ROMEIRO MAT. 2010. Realce do gradiente horizontal total de anomalias magnéticas usando a inclinação do sinal analítico. Parte I - Aplicação a dados sintéticos. In: Simpósio Brasileiro de Geofísica, 4: 2010, Brasília, DF. CD-ROM. 
FORNAZZARI NETO L \& FERREIRA FJF. 2003. Gamaespectrometria integrada a dados exploratórios multifonte em ambiente SIG aplicada à prospecção de ouro na Folha Botuverá, SC. Revista Brasileira de Geociências, 33(2): 197-208.

GEOSOFT. 2011. Mapping and Processing System - The core software platform for working with large volume spatial data. Quick Start ${ }^{\mathrm{TM}}$ Tutorials. Available on: <http://www.geosoft.com/support/downloads/technicaldocumentation > . Acces on: April 15, 2011.

GNOJEK I \& PRICHYSTAL A. 1985. A new zinc mineralization detected by airborne gamma-ray spectrometry in northern Moravia (Czechoslovakia). Geoexploration, 23(4): 491-502.

GRASTY RL, GLYNN JE \& GRANT JA. 1985. The analysis of multichannel airborne gamma-ray spectra. Geophysics, 50: 2611-2620.

GUNN S. 1998. Support Vector Machines for Classification and Regression. Technical Report MP-TR-98-05, Image Speech and Intelligent Systems Group, University of Southampton, Southampton, 52 pp.

HOOVER DB \& PIERCE HA. 1990. Annotated Bibliography of GammaRay Methods Applied to Gold Exploration. USGS Open-File Report, p. 90-203.

LAMMOGLIA T. 2006. Caracterização de Microexsudações de Hidrocarbonetos na Bacia do Tucano Norte (BA) por geoestatística, classificação hiperespectral e Redes Neurais. Final graduation paper, Instituto de Geociências, Universidade Estadual de Campinas, Campinas, 83 pp.

LI X. 2006. Understanding 3D analytic signal amplitude. Geophysics, 71(2): L13-L16.

LI X. 2008. Magnetic reduction-to-the-pole at low latitudes: Observations and considerations. The Leading Edge, 27(8): 990-1002.

LOONEY CG \& YU H. 2000. Special Software Development for Neural Network and Fuzzy Clustering Analysis in Geological Information Systems. Geological Survey of Canada, 34 pp.

MAGALHÃES LA \& SOUZA FILHO CR. 2012. Targeting of Gold Deposits in Amazonian Exploration Frontiers using Knowledge and Data-Driven Spatial Modeling of Geophysical, Geochemical, and Geological Data. Surv. Geophys., doi: 10.1007/s10712-011-9151-1.

MIGUEL Jr E. 2011. Controle estrutural das mineralizações auríferas e idade U-Pb das encaixantes ao longo do lineamento Peru-Trairão: Província Aurífera de Alta Floresta, Mato Grosso. Master Dissertation - Instituto de Geociências, Universidade Estadual de Campinas, Campinas. $66 \mathrm{pp}$.

MILLER HG \& SINGH V. 1994. Potential field tilt - a new concept for location of potential field sources. J. Appl. Geophys., 32(2-3): 213-217.

MORETON LC \& MARTINS EG. 2000. Peixoto de Azevedo Gold District Geology, Mato Grosso State, Amazon Craton, Brasil. In: International Geological Congress, 31: 2000, Rio de Janeiro, Rio de Janeiro. CD-ROM.
MORETON LC \& MARTINS EG. 2005. Geologia e Recursos Minerais de Alta Floresta - Vila Guarita. Escala 1:250.000. Brasília: Serviço Geológico do Brasil (CPRM). 68 pp.

MOURA MA. 1998. 0 Maciço Granítico Matupá e o Depósito de Ouro Serrinha (MT): Petrologia, Alteração Hidrotermal e Metalogenia. PhD Thesis, Instituto de Geociências, Universidade de Brasília, Brasília, $238 \mathrm{pp}$.

MOURA MA \& BOTELHO NF. 2002. Petrologia do magmatismo associado à mineralização do tipo ouro pórfiro na Província Aurífera Juruena - Teles Pires (MT). Revista Brasileira de Geociências, 32: 377-386.

MOURA MA, BOTELHO NF, OLIVO GR \& KYSER TK. 2006. Graniterelated Paleoproterozoic, Serrinha gold deposit, Southern Amazonia, Brazil: hydrothermal alteration, fluid inclusion and stable isotope constraints on genesis and evolution. Econ. Geol., 101: 585-605.

NABIGHIAN MN. 1972. The analytic signal of two-dimensional magnetic bodies with polygonal cross-section: Its properties and use for automated anomaly interpretation. Geophysics, 37(3): 507-517.

NABIGHIAN MN. 1974. Additional comments on the analytic signal of two-dimensional magnetic bodies with polygonal cross-section. Geophysics, 39(1): 85-92.

OLIVEIRA CC \& ALBUQUERQUE MC. 2003. Projeto Província Mineral de Alta Floresta (PROMIN ALTA FLORESTA). Geologia e Recursos Minerais da Folha Alta Floresta - SC. 21-Z-X-C. Programa Levantamentos Geológicos Básicos do Brasil (PLGB), CPRM, Brasília.

OSTROVSKY EA. 1975. Antagonism of radioactive elements in wallrock alteration fields and its use in aerogamma spectrometric prospecting. Int. Geol. Rev., 17: 461-468.

PAES DE BARROS AJ. 1994. Contribuição a geologia e controle das mineralizações auríferas de Peixoto de Azevedo - MT. Master Dissertation, Instituto de Geociências, Universidade de São Paulo, São Paulo, $145 \mathrm{pp}$.

PAES DE BARROS AJ. 2007. Granitos da região de Peixoto de Azevedo Novo Mundo e mineralizações auríferas relacionadas - Província Aurífera de Alta Floresta (MT). PhD Thesis - Instituto de Geociências, Universidade Estadual de Campinas, Campinas, 154 pp.

PARRO PS. 1998. Magnetometria e gamaespectrometria aerotransportadas na interpretação geológico-estrutural da região dos rios Juruena e Teles Pires. Master Dissertation - Instituto de Geociências, Universidade de Brasília, Brasília, 63 pp.

PIRES ACB. 1995. Identificação geofísica de áreas de alteração hidrotermal, Crixás-Guarinos, Goiás. Revista Brasileira de Geociências, 25(1): $61-68$.

RIZZOTTO GJ, QUADROS MLES, BAHIA RBC, FERREIRA RBC, LOPES RC \& CORDEIRO AV. 2004. Folha SC.21-Juruena. In: SCHOBBENHAUS C, GONÇALVES JH, SANTOS JOS, ABRAM MB, LEÃO NETO R, MATOS 
GMM, VIDOTTI RM, RAMOS MAB \& JESUS JDA (Eds.). Carta Geológica do Brasil ao milionésimo. Sistema de Informações Geográficas. 46 foIhas na escala 1:1.000.000. Programa Geologia do Brasil, Brasília, Serviço Geológico do Brasil (CPRM), 41 CD-ROM, ISBN 85-7499-099-4.

ROEST WR, VERHOEF J \& PILKINGTON M. 1992. Magnetic interpretation using the 3-D analytic signal. Geophysics, 57(1): 116-125.

RUDNICK R \& GAO S. 2004. Composition of the continental crust. In: HOLLAND HD \& TUREKIAN KK (Eds.). Treatise on geochemistry. Oxford: Elsevier Pergamon, 3: 1-64.

SANTOS JOS. 2003. Geotectônica dos escudos das Guianas e BrasilCentral [Geotectonics of the Guyana and Central Brazilian Shields]. In: BIZZI LA, SCHOBBENHAUS C, VIDOTTI RM \& GONÇALVES JH (Eds.). Geologia, Tectônica e Recursos Minerais do Brasil [Geology, Tectonics and Mineral Resources of Brazil]. CPRM: Brasília, p. 169-226.

SANTOS JOS, HARTMANN LA, GAUDETTE HE, GROVES DI, McNAUGHTON NJ \& FLETCHER IR. 2000. A new understanding of the Provinces of the Amazon Craton based on integration of field mapping and U-Pb and Sm-Nd geochronology. Gondwana Res., 3(4): 453-488.

SANTOS JOS, GROVES DI, HARTMANN LA, MOURA MA \& McNAUGHTON NJ. 2001. Reply to the discussion on "Gold deposits of the Tapajós and Alta Floresta domains, Tapajós-Parima orogenic belt, Amazon Craton, Brazil". Miner. Deposita, 36: 278-299.

SANTOS JOS, HARTMANN LA, FARIA MSG, RIKER SR, SOUZA MM, ALMEIDA ME \& McNAUGHTON NJ. 2006. A compartimentação do Cráton Amazonas em províncias: avanços ocorridos no período 20002006. In: SBG-NO, Simpósio de Geologia da Amazônia, 9, Belém. CD-ROM.

SAUNDERS DF, TERRY SA \& THOMPSON CK. 1987. Test of National Uranium Resource Evaluation gamma-ray spectral data in petroleum reconnaissance. Geophysics, 52(11): 1547-1556.

SINGH B \& GUPTASARMA D. 2001. New method for fast computation of gravity and magnetic anomalies from arbitrary polyhedra. Geophysics, 66(2): 521-526.
SILVA MG \& ABRAM MB. 2008. Projeto metalogenia da Província Aurífera Juruena-Teles Pires, Mato Grosso. Goiânia, Serviço Geológico do Brasil, CPRM, 212 pp.

SILVA GH, LEAL JWL, MONTALVÃO RMG, BEZERRA PEL, PIMENTA ONS, TASSINARI CCG \& FERNANDES CAC. 1980. Geologia da Folha SC 21 Juruena. DNPM, Projeto Radam-Brasil, 20: 25-116.

SOUZA JO, FRASCA AAS \& OLIVEIRA CC. 2005. Geologia e Recursos Minerais da Província Mineral de Alta Floresta (Relatório Integrado). Brasília: CPRM-Programa Levantamentos Geológicos Básicos do Brasil (PLGB), 159 pp.

TASSINARI CCG \& MACAMBIRA MJB. 1999. Geochronological Provinces of the Amazonian Craton. Episodes, 22(3): 174-182.

THOMPSON DT. 1982. EULDPH: A new technique for making computer assisted depth estimates from magnetic data. Geophysics, 47(1): 31-37.

ULBRICH HHG, ULBRICH MNC, FERREIRA FJF, ALVES LS, GUIMARÃES GB \& FRUCHTING A. 2009. Levantamentos Gamaespectrométricos em Granitos Diferenciados I: Revisão da Metodologia e do Comportamento Geoquímico dos Elementos K, The U. Revista do Instituto de Geociências - USP, 9(1): 33-53.

VASQUEZ ML, RICCI PS \& KLEIN EL. 2002. Granitóides pós-colisionais da porção leste da Província Tapajós. In: KLEIN EL, VASQUEZ ML \& ROSA-COSTA LT (Eds.); Contribuições à geologia da Amazônia. Belém: SBG, 3: 67-84.

VERDUZCO B, FAIRHEAD JD, GREEN CM \& MACKENZIE C. 2004. New insights into magnetic derivatives for structural mapping. The Leading Edge, 23(2): 116-119.

WIJNS C, PEREZ C \& KOWALCZYK P. 2005. Theta map: Edge detection in magnetic data. Geophysics, 70(4): L39-L43.

XAVIER RP, ASSIS RR, MIGUEL Jr E, SANTOS TJS \& PAES DE BARROS AJ. 2011. Gold \pm copper and gold-base metal deposits associated with granitic systems in the eastern sector of the Alta Floresta Province (MT). In: Simpósio de Geologia da Amazônia, 12: 2011, Boa Vista, RR. CD-ROM.

Recebido em 19 março, 2012 / Aceito em 2 julho, 2012

Received on March 19, 2012 / Accepted on July 2, 2012

\section{NOTES ABOUT THE AUTHORS}

Danilo Barbuena. Geologist from the University of Campinas (UNICAMP) and Masters in Geosciences (geophysics and remote sensing applied to mineral exploration) from the University of Campinas (UNICAMP). He is currently a PhD student (evolution of Archean terrains) at the University of Campinas (UNICAMP). He has experience in Geosciences with an emphasis in Geophysics, Remote Sensing and Mineral Exploration.

Carlos Roberto de Souza Filho. Graduated in Geology (Universidade Federal de Ouro Preto, 1988), Masters in Metallogenesis (UNICAMP, 1991), Ph.D. (Open University, England, 1995, Young-Researcher (FAPESP-UNICAMP, 1995-1997), Professor-Doctor (UNICAMP, 1997-2002). Currently, he is a Professor at Geology and Natural Resources Department of the Geosciences Institute (IG) of UNICAMP and Coordinator of the Graduate Program and leader of the Geotechnology Group of 
IG. He is Researcher level 1A of CNPq, responsible for the research laboratories of Fs-LA-ICP-MS (IsoGeo), Reflectance Spectroscopy (RSI) and Information Processing Geo-referenced (LAPIG). He is a NASA researcher for the ASTER and Mars-Earth Analogs programs, Associate Editor of the journals Computers \& Geosciences, and Mathematical Geology.

Francisco José Fonseca Ferreira. Graduated in Geology from the Universidade Federal de Pernambuco (1970), specialized in Applied Geophysics at Universidade Federal da Bahia (1974). Received Master (1982) and Ph.D. (1991) degrees in Geosciences from the Universidade de São Paulo. Developed professional activities in CPRM (1972-1980) and IPT (1981-1990). Currently, is an Associate Professor III in the Geology Department of the Universidade Federal do Paraná (UFPR) and Coordinator of the Research and Applied Geophysics Laboratory. Has experience in Geosciences, with emphasis in Applied Geophysics, acting especially in the following areas: airborne and land geophysics applied to mineral prospection, underground water and to the environment.

Emilson Pereira Leite. Geophysicist from the Universidade de São Paulo (1997) received the Master (2000) and Ph.D. (2005) degrees in Geophysics from the Universidade de São Paulo. He was a trainee at the Department of Earth and Space Science and Engineering at York University, Canada. He is currently Professor of Geophysics in the Geology and Natural Resources Department of the Geosciences Institute of UNICAMP. His area of expertise is Geophysics on the following topics: geophysical data inversion and integration, geological and remote sensing applied to mineral and hydrocarbons exploration.

Emílio Miguel Junior. Mining Technician from the Escola Técnica Federal de Goiás (1999), graduated in Geology from the Universidade Federal de Mato Grosso (2008), and received a Master degree in Geosciences from the Universidade Estadual de Campinas (2011). He works in the field of Geosciences with emphasis in structural geology, gold mining, mining ordering and mineral research.

Rafael Rodrigues de Assis. Graduated in Geology from the Universidade Estadual de Campinas (2008) and received his Master degree (2011) from the Universidade Estadual de Campinas. He works in Geosciences, with emphasis on the field of metallogenesis (main research area), Petrography and Petrogenesis, Fluid Inclusions and Environmental Geochemistry. Works mainly with fluid characterization and evolution in the formation of hydrothermal alteration zones, with respect to orogenetic Au deposits, Cu-Au associated with felsic intrusion and porphyry type systems.

Roberto Perez Xavier. Geologist from the Universidade de São Paulo (1981), Master in Geosciences from the Universidade de São Paulo (1987), Doctor of metallogeny by the University of Southampton/UK (1991) and post-doctoral training (2007-2008) in Economic Geology Research Unit of the James Cook University (Australia). He is currently a professor of Economic Geology in the Geology and Natural Resources Department of the Geosciences Institute of UNICAMP. Has experience in metallogeny, with emphasis on the characterization and evolution of fluids in the formation of hydrothermal alteration zones and associated mineral deposits.

Antônio João Paes de Barros. Graduated in Geology from the Universidade Federal de Mato Grosso (1981), received his Master degree in Geosciences (Mineral Resources and Hydrogeology) from the University of São Paulo (1990) and Ph.D. in Geosciences from the Universidade Estadual de Campinas (2007). Currently, he works as a Geologist in the Companhia Matogrossense de Mineração. Has experience in Geosciences with emphasis on metallogeny, on the following topics: gold mining, mining ordering, limestone research, environmental management and mining reclamation. 